\title{
Editorial retraction of a paper
}

\author{
Colin Ratledge
}

Published online: 14 February 2007

C) Springer Science+Business Media B.V. 2007

\section{Erratum to: Biotechnol Lett (2006) 28: 189-196 DOI 10.1007/s10529-005-5334-5}

Caspase-3 induced apoptosis in transgenic zebrafish by Chiranjib Chakraborty, Gargi Saha, Biplab Sarkar, S. Pal, T.K. Chatterjee and A.K. Sadhu was published in this journal in the February I (2006) issue (Biotechnology Letters 2006, 28: 189196).

It was subsequently brought to our attention that three of its six figures (Figs. 2, 5 and 6) were derived from a paper on a different research topic that had been published three years earlier in Science by a different research group: MycInduced $\mathbf{T}$ cell Leukemia in Transgenic Zebrafish by D.M. Langenau, D. Traver, A.A. Ferrando, J.L. Kutok, J.C. Aster, J.P. Kanki, S. Lin, E. Prochownik, N.S. Trede, L.I. Zon, A.T. Look, Science 299: 887-890 (2003).

These three figures, which formed a key part of the Chakraborty et al. paper, were photographically manipulated versions of those in the Langenau et al. Science paper but had been made to appear as if they were original material. Detailed

The online version of the original article can be found at http://dx.doi.org/10.1007/s10529-005-5334-5

C. Ratledge $(\bowtie)$

University of Hull, Hull, UK

e-mail: c.ratledge@hull.ac.uk analysis of these figures, which presented wholeanimal images and histological sections of zebrafish, as well as FACS analyses of kidney and testis cells, revealed that the authors of the Chakraborty et al. paper had used data in the Langenau et al. Science paper in a deliberate and fraudulent manner with the clear intention of deceiving the editor, the reviewers of the paper and, most importantly, the readers of the paper. Furthermore, it was found that there were considerable textual similarities between the two papers; the Chakraborty et al. paper contained several complete paragraphs and sections of text that were derived from the Langenau et al. Science paper.

The editors of Science and Biotechnology Letters have concluded that the Chakraborty et al. paper is fraudulent and must be discounted by the scientific community as having no validity or substance. This paper is therefore being editorially retracted.

Dr. Chakraborty, when contacted by email with this information, has admitted responsibility for using the data of Langenau et al. in a fraudulent manner, including photomanipulation of the key figures, and for plagiarizing the text in an attempt to present other researchers' data as his own work.

All the other listed authors on this paper have been contacted by the editor; all of them have stated that they knew nothing of this paper. At no time had Chakraborty informed them of their 
inclusion as co-authors even following publication of the paper. Furthermore, they state that they had not been involved with any part of the work nor had they provided any information to Chakraborty that pertained to the contents of the paper.

It would also appear that three of the four affiliations, listed by Dr. Chakraborty as places where he himself had worked or had been associated with during the course of this work, were false attributions; we could find no record of Dr Chakraborty having worked at the Marine
Aquarium and Research Center, Digha, West Bengal, at the Department of Industrial Fish and Fishery, Burdwan, West Bengal or at Jadavpur University, Calcutta.

It is with considerable regret that we have to make this announcement of scientific fraud as it impinges upon everyone's integrity and the good name of science in general.

Colin Ratledge, Editor-in-Chief of Biotechnology Letters 